\title{
RAÎNSTEK
}

\section{PENGARUH PROBLEM POSING LEARNING TERHADAP KREATIVITAS PESERTA DIDIK SMP NEGERI 12 MALANG}

\author{
Minarsih $^{1}$, I Ketut Suastika ${ }^{2}$, Nyamik Rahayu Sesanti ${ }^{3}$ \\ Prodi Pendidikan Matematika, Universitas Kanjuruhan Malang ${ }^{1,2,3}$ \\ Minarsih.6010@gmail.com ${ }^{1}$, suastika@unikama.ac.id ${ }^{2}$,nyamik@unikama.ac.id ${ }^{3}$
}

\begin{abstract}
Abstrak. Penelitian ini bertujuan untuk mengetahui adanya pengaruh model problem posing learning terhadap kreativitas peserta didik SMP Negeri 12 Malang. Penelitian ini merupakan penelitian quasi experimental design atau eksperimen semu yang menggunakan desain penelitian nonequivalent control grup design. Model pembelajaran problem posing sebagai variabel bebas dan kreativitas peserta didik sebagai variabel terikat. Populasi dalam penelitian ini adalah seluruh peserta didik kelas VIII SMP Negeri 12 Malang Tahun Pelajaran 2017/2018. Sampel penelitian ini terdiri dari dua kelas yaitu kelas VIII B sebagai kelas eksperimen dan kelas VIII C sebagai kelas kontrol. Teknik pengambilan sampel yang digunakan adalah teknik sampling purposive. Teknik pengumpulan data menggunakan tes yang terdiri dari pretest dan posttest serta dokumentasi. Teknik analisis data dengan menggunakan uji-t (T-test) untuk menguji hipotesis. Hasil uji hipotesis pengaruh model problem posing learning terhadap kreativitas peserta didik diperoleh nilai sign. $<0,05$ yang artinya $\mathrm{H}_{0}$ ditolak sehingga hipotesis diterima. Besar pengaruh model pembelajaran problem posing sebesar $62,38 \%$ yang artinya model pembelajaran problem posing cukup berrpengaruh terhadap kreativitas peserta didik. Berdasarkan hasil penelitian dapat disimpulkan bahwa ada pengaruh model problem posing learning terhadap kreativitas peserta didik SMP Negeri 12 Malang. Model pembelajaran problem posing dapat digunakan dalam pembelajaran guna meningkatkan kreativitas peserta didik.
\end{abstract}

Kata Kunci: pembelajaran kooperatif, talking stick, dadu, power point

\section{PENDAHULUAN}

Peserta didik banyak yang menganggap bahwa matematika dan kreativitas tidak ada hubungannya, padahal pendapat ini merupakan pemikiran yang salah. Kurikulum 2013 adalah kurikulum yang digunakan di Indonesia saat ini yang memiliki karakteristik, salah satunya adalah menitikberatkan pembelajaran yang mengembangkan kreativitas peserta didik. Hal ini tercantum dalam Peraturan Menteri Pendidikan dan Kebudayaan Nomor 22 Tahun 2016, yang berbunyi "proses pembelajaran pada satuan pendidikan diselenggarakan secara interaktif, inspiratif, menyenangkan, menantang, memotivasi peserta didik untuk berpartisipasi aktif, serta memberikan ruang yang cukup bagi prakarsa, kreativitas, dan kemandirian sesuai dengan minat, bakat dan perkembangan fisik serta psikologis peserta didik". Pengembangan kreativitas peserta didik, memiliki perhatian lebih dari pemerintah, terlihat dari penerapan kurikulum sebelumnya yaitu kurikulum 2006 juga memiliki tujuan mengembangkan potensi peserta didik dalam kegiatan belajar dan pembelajaran, salah satu potensi yang dikembangkan yaitu kreativitas peserta didik.

Menurut Silver (1997) kreativitas dipandang sebagai kemampuan individu jenius yang mampu menggunakan kemampuan berpikir dan bertindak kreatif untuk digunakan sebagai fondasi yang jauh lebih kuat dalam mengaplikasikan pendidikan. Sedangkan menurut Menurut Siswono (2009) kreativitas adalah kemampuan berpikir kreatif yang dapat diukur dengan memberikan tes pada tiga indikator yaitu kelancaran (fluency), fleksibilitas (flexibility), dan orisinalitas/kebaruan (originality). Siswono (2004) juga menyatakan bahwa kreativitas adalah produk dari berpikir kreatif. Moma (2015:29) menyatakan bahwa "berpikir kreatif adalah 
aktivitas mental yang terkait dengan kepekaan terhadap suatu masalah, mempertimbangkan informasi baru dan ide-ide yang tidak biasanya dengan suatu pikiran terbuka peserta didik menggunakan kemampuan berpikir terbuka serta berkaitan dengan penyelesaian masalah". Sehingga dapat diketahui bahwa kreativitas sangat diperlukan tidak hanya dalam seni namun juga dalam matematika karena dengan kreativitas peserta didik dapat menggunakan kreativitas yang dimiliki untuk mendatangkan ide atau memodifikasi ide-ide lama menjadi ide baru. Mahmudi (2008) juga menyatakan bahwa kreativitas merupakan potensi yang dapat dikembangkan, kreativitas tidak hanya dikaitkan pada bidang-bidang tertentu, melainkan dapat merujuk pada semua bidang, termasuk matematika. Dalam penelitiannya Mahmudi (2008) menyimpulkan bahwa kreativitas dalam matematika dapat sebagai dasar untuk merancang pembelajaran matematika yang dapat menstimulasi pengembangan kreativitas peserta didik.

Pembelajaran di sekolah saat ini sangat bertolak belakang dengan tuntutan pemerintah mengenai mengembangkan kreativitas peserta didik. Menurut Suastika (2017), the learning done by the teacher in the class still has not emphasized the developmentof the creativity of the student. The result of the current study of mathematical learning conditions are as follows: 1) Learning tends to be teacher centered; 2) Students are poorly trained in solving open problem that allow for many answer or different solutions; 3) Evaluation made emphasize more on mastery aspects of teaching materials, aspects related to students mathematics creativity is almost never touched. Sehingga dalam pembelajaran di sekolah peserta didik hanya dituntut untuk menyelesaikan masalah yang bertujuan untuk mengetahui pemahaman konsep atau isi peserta didik terhadap suatu materi tanpa menyentuh kreativitas peserta didik.

Penelitian tentang meningkatkan kreativitas melalui pengajuan masalah juga telah dilakukan Siswono (2007) yang menyimpulkan bahwa pengajuan masalah dalam pembelajaran matematika dapat meningkatkan atau mengembangkan kreativitas peserta didik dalam pembelajaran matematika. Dalam penelitiannya, Siswono (2007) menekankan pada pembelajaran dengan metode masalah yang mampu mempengaruhi kreativitas peserta didik, salah satunya pengajuan masalah. Sugihardjo, Mardiyana dan Riyadi (2014) juga mengatakan bahwa cara lain untuk mempengaruhi kreativitas peserta didik adalah dengan menggunakan model pembelajaran problem posing yaitu pembuatan soal, pertanyaan atau pernyataan yang terkait soal atau situasi tertentu. Menurut Mahmudi (2007), problem posing adalah mengajukan masalah baru atau merumuskan ulang dari masalah yang telah diberikan. Selain itu, menurut Zakaria dan Ngah (2011) menyatakan bahwa pengajuan masalah oleh peserta didik dapat meningkatkan keterampilan pemecahan masalah peserta didik, aktivitas ini secara langsung membantu peserta didik untuk berpikir kreatif dan kritis seperti yang diharapkan oleh Kementerian Pendidikan.

Silver (1997) menyatakan hubungan kreativitas dengan problem posing learning yaitu, (1) Kefasihan/kelancaran (fluency) yaitu peserta didik dapat mengajukan berbagai masalah atau banyak masalah yang memiliki penyelesaian, (2) Fleksibiltas (flexibility) yaitu peserta didik dapat mengajukan masalah yang memiliki penyelesaian yang beragam atau bervariasi, (3) Orisinalitas yaitu peserta didik mampu menyelesaiakan masalah yang dibuat serta mampu mengajukan masalah yang baru atau berbeda dari soal yang telah diselesaikan. Penggunaan model pembelajaran problem posing learning akan mampu mempengaruhi kreativitas peserta didik sehingaa peserta didik mampu menyelesaikan masalah yang memiliki banyak penyelesaian dengan kreativitas yang dimilikinya. Menurut Moma (2015) dengan pengajuan masalah peserta didik dapat menyelesaikan masalah yang memiliki banyak jawaban atau banyak cara dengan ciri-ciri seperti berikut: (1) Kelancaran (fluency): mencetuskan banyak gagasan dalam pemecahan masalah, memberikan banyak jawaban dalam menjawab suatu pertanyaan,b memberikan banyak cara atau saran untuk melakukan berbagai hal, bekerja lebih cepat dan melakukan lebih banyak daripada anak-anak lain; (2) Fleksibilitas (flexibility): menghasilkan variasi-variasi gagasan penyelesaian masalah atau jawaban suatu pertanyaan, dapat melihat suatu masalah dari sudut pandang yang berbeda-beda, menyajikan suatu konsep dengan cara yang berbeda-beda: serta (3) orisinalitas (originality) : memberikan gagasan yang relative baru dalam menyelesaikan masalah atau jawaban yang lain dari yang sudah biasa dalam menjawab suatu pertanyaan, membuat kombinasi-kombinasi yang tidak lazin dari bagian-bagian atau unsur-unsur. Pengukuran kreativitas peserta didik pada masing-masing masalah yang diberikan 
menggunakan kriteria pedoman penskoran yang dimodifikasi dari pedoman penskoran dalam penelitian Suastika (2015). Penskoran untuk indikator-indikator kreativitas diberikan pada Tabel 1 berikut.

Tabel 1. Pedoman Penskoran Kreativitas Peserta Didik

\begin{tabular}{|c|c|c|}
\hline Aspek kretivitas & Deskriptor & Skor \\
\hline \multirow{6}{*}{ Kefasihan (fluency) } & Tidak memberikan jawaban & 0 \\
\hline & Memberikan jawaban namun salah & 1 \\
\hline & $\begin{array}{l}\text { Memberikan dua jawaban namun hanya satu yang benar atau hanya } \\
\text { memberikan satu jawaban benar }\end{array}$ & 2 \\
\hline & Memberikan dua jawaban dengan hasil benar atau memberikan & 3 \\
\hline & lebih dari dua jawaban namun terdapat jawaban yang salah & \\
\hline & Memberikan lebih dari dua jawaban dengan hasil benar & 4 \\
\hline \multirow{5}{*}{$\begin{array}{l}\text { Fleksibilitas } \\
\text { (flexibility) }\end{array}$} & Tidak memberikan jawaban & 0 \\
\hline & Memberikan satu alternatif penyelesaian namun salah & 1 \\
\hline & $\begin{array}{l}\text { Memberikan dua alternatif penyelesaian namun hanya satu yang } \\
\text { benar atau hanya memberikan satu alternatif penyelesaian dengan } \\
\text { hasil benar }\end{array}$ & 2 \\
\hline & $\begin{array}{l}\text { Memberikan dua alternatif penyelesaian dengan hasil benar atau } \\
\text { memberikan lebih dari dua alternatif penyelesaian namun masih } \\
\text { terdapat hasil yang salah }\end{array}$ & 3 \\
\hline & $\begin{array}{l}\text { Memberikan lebih dari dua alternatif penyelesaian dengan hasil } \\
\text { benar }\end{array}$ & 4 \\
\hline \multirow{5}{*}{$\begin{array}{l}\text { Keaslian } \\
\text { (originality) }\end{array}$} & Tidak memberikan jawaban & 0 \\
\hline & $\begin{array}{l}\text { Memberikan alternatif penyelesaian yang berbeda tetapi tidak dapat } \\
\text { dipahami }\end{array}$ & 1 \\
\hline & $\begin{array}{l}\text { Memberikan alternative penyelesian yang berbeda, proses } \\
\text { perhitungan terarah tetapi tidak selesai }\end{array}$ & 2 \\
\hline & $\begin{array}{l}\text { Memberikan alternative penyelesaian yang berbeda tetapi terdapat } \\
\text { kekeliruan dalam proses perhitungan sehingga hasil salah }\end{array}$ & 3 \\
\hline & $\begin{array}{l}\text { Memberikan alternative penyelesaian, proses perhitungan dan hasil } \\
\text { benar. }\end{array}$ & 4 \\
\hline
\end{tabular}

\section{METODE PENELITIAN}

Pendekatan penelitian ini adalah penelitian kuantitatif dengan jenis penelitian eksperimen. Desain penelitian eksperimen yang digunakan adalah quasi experimental design. Quasi experimental design adalah pengembangan dari true experimental design yang sulit dilakukan. Desain ini memiliki kelompok kontrol tetapi tidak berfungsi sepenuhnya untuk mengontrol variabel-variabel luar yang mempengaruhi pelaksanaan eksperimen (Sugiyono, 2015:77).

Penelitian ini menggunakan nonequivalent control group design sehingga dalam penelitian ini terdapat dua kelas yang selanjutnya diberikan pretest dengan tujuan untuk mengetahui kemampuan awal kedua kelompok selain itu digunakan untuk mengetahui bahwa kedua kelas dari varians yang sama dan diharapkan tidak ada perbedaan yang signifikan antara kedua kelompok. Selanjutnya kelas eksperimen diberikan perlakuan (treatment) sesuai dengan variabel, sedangkan kelas kontrol diberikan pembelajaran konvensional, dan untuk mengetahui pengaruh treatment yaitu problem posing learning, pada tahap akhir kedua kelas diberikan posttest. Hasil yang didapatkan dari posttest diharapkan mampu mengetahui adanya pengaruh problem posing learning terhadap kreativitas peserta didik. Pola rancangan tersebut digambarkan sebagai berikut:
$\mathrm{O} 1 \mathrm{X} \mathrm{O} 2$
O3 O4

Nonequivalent control group design (Sugiyono, 2015)

Keterangan: 

kelas kontrol

$\mathrm{O}$ : Tes tertulis yang diberikan pada pretest dan posttest di kelas eksperimen maupun di

$\mathrm{X}$ : Perlakuan pada kelas eksperimen berupa pembelajaran problem posing

Penelitian ini bertujuan untuk mengetahui adanya pengaruh problem posing learning terhadap kreativitas peserta didik SMP Negeri 12 Malang. Sampel dalam penelitian ini adalah peserta didik kelas VIII B sebagai kelas eksperimen dan kelas VIII C sebagai kelas kontrol.

\section{HASIL DAN PEMBAHASAN}

Instrumen tes sebelum diberikan kepada peserta didik kelas eksperimen dan kelas dilakukan uji validitas untuk mengetahui valid tidaknya setiap butir soal dan uji reliabelitas untuk mengetahui tes dapat digunakan dalam situasi yang lain juga. Tes yang akan diuji adalah pretest dan posttest yang langsung diujikan kepada peserta didik yang memiliki karakteristik yang sama dengan peserta didik pada kelas kontrol dan kelas kontrol namun tidak diperbolehkan berasal dari peserta didik kelas eksperimen maupun kelas kontrol.

\section{Uji Validitas Pretest dan Posttest}

Nilai tes hasil uji coba diuji dengan menggunakan IBM SPSS Statistics 22. Suatu instrumen dikatakan valid apabila koefisien korelasi dan dikatakan tidak valid jika pada taraf signifikan 5\%. Adapun hasil uji validitas ditunjukkan pada

Tabel 2 berikut.

Tabel 2. Hasil Uji Validitas Pretest

\begin{tabular}{ccccccc}
\hline No Soal & $\begin{array}{c}\text { Nilai Pearson } \\
\text { Correlation / }\end{array}$ & Sign. & N & & Keterangan & Kriteria \\
\hline 1 & 0,648 & 0,043 & 10 & 0,632 & $0,648>0,632$ & Valid \\
2 & 0,678 & 0,031 & 10 & 0,632 & $0,678>0,632$ & Valid \\
3 & 0,769 & 0,009 & 10 & 0,632 & $0,769>0,632$ & Valid \\
\hline
\end{tabular}

Berdasarkan Tabel 2 diperoleh bahwa ketiga soal pretest sudah dikatakan valid karena dari perhitungan terlihat bahwa dengan signifikan 0,05 .

Tabel 3. Hasil Uji Validitas Posttest

\begin{tabular}{ccccccc}
\hline No Soal & $\begin{array}{c}\text { Nilai Pearson } \\
\text { Correlation / }\end{array}$ & Sign. & N & & Keterangan & Kriteria \\
\hline 1 & 0,722 & 0,018 & 10 & 0,632 & $0,722>0,632$ & Valid \\
2 & 0,882 & 0,001 & 10 & 0,632 & $0,882>0,632$ & Sangat Valid \\
3 & 0,779 & 0,008 & 10 & 0,632 & $0,779>0,632$ & Valid \\
\hline
\end{tabular}

bahwa dengan signifikan 0,05 .

\section{Uji Reliabilitas Pretest dan Posttest}

Tes dinyatakan reliabel jika mempunyai nilai koefisien alpha. Adapun hasil reliabilitas pretest dapat ditunjukkan pada tabel 4 .

Tabel 4. Hasil Uji Reliabilitas Pretest

\begin{tabular}{|c|c|c|}
\hline Cronbach's Alpha & N of Items & Kriteria \\
\hline 0,765 & 4 & Reliabel \\
\hline
\end{tabular}


Berdasarkan hasil dari Tabel 4 diperoleh nilai Cronbach's Alpha sebesar 0,765 artinya ketiga soal pretest reliabel atau konsisten.

Tabel 5. Hasil Uji Reliabilitas Posttest

\begin{tabular}{|c|c|c|}
\hline Cronbach's Alpha & N of Items & Kriteria \\
\hline 0,822 & 4 & Sangat reliabel \\
\hline
\end{tabular}

Berdasarkan hasil dari Tabel 5 diperoleh nilai Cronbach's Alpha sebesar 0,822 artinya ketiga soal posttest sangat reliabel atau sangat konsisten.

\section{Nilai Rata-rata Aspek Kreativitas Peserta Didik Kelas Eksperimen dan Kelas Kontrol}

Perbandingan nilai rata-rata kreativitas peserta didik pada kelas kontrol dan kelas eksperimen untuk setiap aspeknya secara lengkap dapat dilihat pada Tabel 6.

Tabel 6. Rata-rata Nilai Aspek Kreativitas Peserta Didik

\begin{tabular}{cccc}
\hline & \multirow{2}{*}{ No. } & \multicolumn{2}{c}{ Rata-Rata } \\
\cline { 3 - 4 } & & Kelas Kontrol & Kelas Eksperimen \\
\hline 1. & Fluency & 60 & 79,58 \\
2. & Flexibility & 48,61 & 63,61 \\
3. & Originality & 13,75 & 43,3 \\
\hline
\end{tabular}

Berdasarkan Tabel 6 dapat dibuat diagram batang perbandingan rata-rata aspek kreativitas kelompok kontrol (pembelajaran konvensional) dan kelompok eksperimen (pembelajaran Problem Posing Learning) seperti ditunjukkan pada Gambar 1.

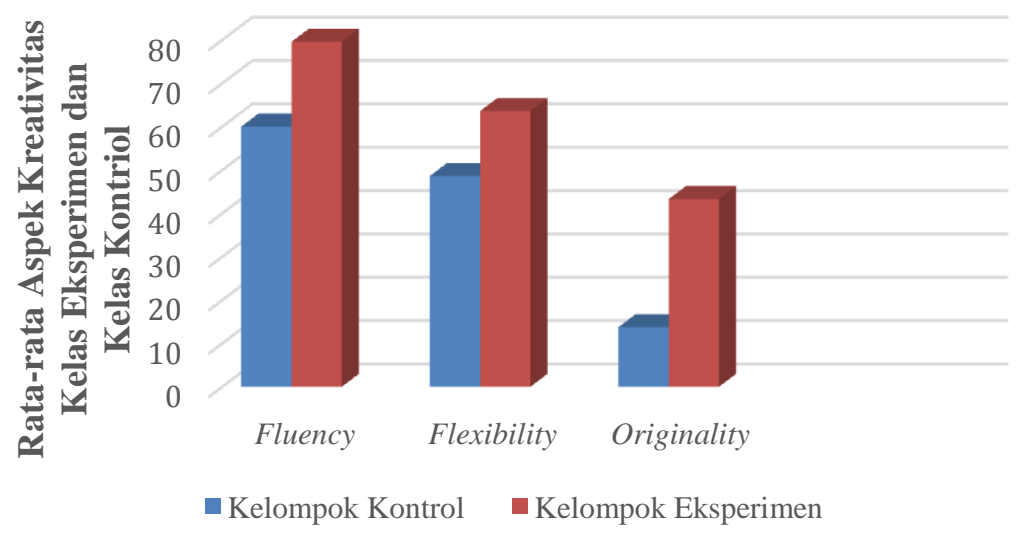

\section{Gambar 1. Perbandingan Rata-rata Nilai Aspek Kreativitas Peserta Didik Kelas Kontrol dan Kelas Eksperimen}

Tabel 6 dan Gambar 1 menunjukkan bahwa rata-rata nilai aspek kreativitas peserta didik pada kelas eksperimen lebih tinggi daripada kelas kontrol. Setiap aspek kreativitas memiliki kenaikan nilai rata-rata antara kelas kontrol dengan kelas eksperimen, dengan kenaikan yang sama.

\section{Uji Normalitas}

Uji normalitas data kreativitas peserta didik kelas kontrol dan kelas eksperimen dilakukan dengan menggunakan uji Kolmogorov-Smirnov dengan dan dibantu dengan IBM SPSS Statistic 22. Jika nilai signifikansi maka diterima artinya sampel berdistribusi normal sedangkan jika nilai signifikansi maka diterima artinya sampel berdistribusi tidak normal. Hasil uji normalitas dapat dilihat pada Tabel 7. 
Tabel 7. Hasil Uji Normalitas Kreativitas Peserta Didik

\begin{tabular}{clccccc}
\hline \multirow{2}{*}{ Tes } & Kelas & $\begin{array}{c}\text { Kolmogorov } \\
\text { Smirnov }\end{array}$ & N & Sig. & \multicolumn{2}{c}{ Hasil } \\
\cline { 6 - 7 } & & & & & Keterangan & Keputusan \\
\hline Pretest & Eksperimen & 0,150 & 30 & 0,085 & $($ sig. $)>0,05$ & Normal \\
& Kontrol & 0,148 & 30 & 0,094 & $($ sig. $)>0,05$ & Normal \\
\multirow{2}{*}{ Posttest } & Eksperimen & 0,128 & 30 & 0,200 & $($ sig. $)>0,05$ & Normal \\
& Kontrol & 0,103 & 30 & 0,200 & $($ sig. $)>0,05$ & Normal \\
\hline
\end{tabular}

Tabel 7 menunjukkan bahwa nilai (sig.) $>0,05$ sehingga keputusan uji diterima. Hal ini disimpulkan bahwa sampel penelitian berasal dari populasi yang berdistribusi normal.

\section{Uji Homogenitas}

Adapun kriteria pengujiannya adalah apabila nilai signifikansi atau probabilitas $<0,05$ maka data berasal dari populasi-populasi yang mempunyai varian tidak sama sedangkan jika nilai signifikansi atau nilai probabilitas $>0,05$ maka data tersebut berasal dari populasi-populasi yang mempunyai varian yang sama. Hasil uji homogenitas dapat dilihat pada Tabel 8.

Tabel 8. Hasil Uji Homogenitas

\begin{tabular}{cccc}
\hline \multirow{2}{*}{ Statistik } & Sig. & \multicolumn{2}{c}{ Hasil } \\
\cline { 3 - 4 } & & Keterangan & Keputusan \\
\hline 2,216 & 0,142 & Homogen
\end{tabular}

Tabel 8 menunjukkan bahwa nilai signifikansi atau nilai probabilitas $>0,05$ maka data tersebut berasal dari populasi-populasi yang mempunyai varian yang sama/homogen.

\section{Uji Hipotesis}

Uji yang digunakan sama-sama menggunakan uji-t dengan kriteria yang digunakan untuk pengambilan keputusan hipotesis adalah tingkat signifikasi ( Hasil uji T-test dapat diketahui, jika nilai Sig. (2-tailed) < 0,05 maka hipotesis terbukti artinya ditolak dan diterima sedangkan jika nilai Sig. (2-tailed) > 0,05 maka hipotesis terbukti artinya ditolak dan diterima. Adapun hipotesis dalam penelitian ini adalah adanya pengaruh antara model Problem Posing Learning terhadap kreativitas peserta didik pada pembelajaran teorema Pythagoras kelas VIII SMP Negeri 12 Malang. Hasil dari uji hipotesis pada penelitian ini dapat dilihat pada Tabel 9 sebagai berikut.

Tabel 9. Hasil Uji Pengaruh Model Problem Posing Learning terhadap Kreativitas Peserta Didik

\begin{tabular}{ccccc}
\hline Variabel & t & df & Sig. (2-tailed) & Keputusan Uji \\
\hline Kreativitas & 4,243 & 58 & 0,000 & $($ sig. $)<0,05$ \\
Peserta Didik & & & & ditolak \\
\hline
\end{tabular}

Tabel 9 menunjukkan hasil keputusan $($ sig. $)<0,05$ sehingga ditolak dan diterima, hal ini berarti perolehan rata-rata nilai kreativitas peserta didik antara kelompok kontrol dengan kelompok eksperimen berbeda nyata. Rata-rata kreativitas peserta didik kelompok eksperimen lebih tinggi daripada kelompok kontrol. Berdasarkan perolehan ini maka hipotesis terbukti artinya ada pengaruh model pembelajaran Problem Posing Learning terhadap 
kreativitas peserta didik. Untuk mengetahui seberapa besar pengaruh model pembelajaran Problem Posing Learning terhadap kreativitas dapat diperoleh melalui rumus :

Jadi besar pengaruh model pembelajaran Problem Posing Learning terhadap kreativitas adalah 62,38\% yang artinya model pembelajaran Problem Posing Learning cukup berpengaruh terhadap kreativitas.

Berdasarkan uji yang telah dilakukan dan mendapatkan hasil bahwa ditolak, maka model problem posing learning berpengaruh terhadap kreativitas peserta didik pada pembelajaran matematika. Hasil keputusan ini ditunjukkan dengan nilai (sign) yaitu 0,00 sehingga (sign) $<0,05$.

Peserta didik mampu berpikir kreatif untuk mendapatkan alternatif penyelesaian yang berbeda atau dengan menggunakan cara sendiri. Selain itu, peserta didik dapat menjadi aktif dengan mengajukan masalah. Hal ini dapat diperoleh setelah peneliti menggunakan model pembelajaran problem posing. Ulfah, Prabawanto, dan Jupri (2017) pada penelitiannya menyimpulkan bahwa penerapan problem posing learning membantu peserta didik untuk lebih aktif serta mampu mengembangkan kreativitas peserta didik. Sehingga model pembelajaran problem posing dapat memfasilitasi peserta didik kemampuan mengajukan masalah yang dapat memberikan pengaruh terhadap kreativitas peserta didik. Selain itu, menurut Mahendra, Slamet dan Budiyono (2017) pembelajaran pengajuan masalah mengajak peserta didik lebih aktif dalam belajar sehingga informasi tidak hanya berasal dari pendidik namun dapat juga dari peserta didik sendiri dengan mengembangkan informasi yang telah diperoleh.

Pembelajaran pengajuan masalah diawali dengan pemberian materi kepada peserta didik mengenai materi penerapan teorema Pythagoras dalam kehidupan sehari-hari. Kemudian peserta didik diberikan lembar problem posing 1 yang digunakan untuk menuliskan soal yang akan diajukan, sebelum itu peserta didik telah dibentuk menjadi beberapa kelompok dengan tujuan peserta didik akan lebih banyak mengajukan soal karena terdapat banyak pemikiran dalam satu kelompok. Pada tahap ini memungkinkan peserta didik untuk mengajukan banyak maslah yang berbeda-beda serta bentuk masalah yang memiliki banyak penyelesaian. Soal yang telah diajukan akan ditukarkan kepada kelompok lain dan kelompok lain diminta untuk mengerjakan soal tersebut pada lembar problem posing 2. Pada tahap ini pula peserta didik akan menggunakan kemampuan kreativitas yang dimiliki peserta didik untuk dapat menyelesaikan masalah tersebut serta akan lebih aktif dan kritis untuk mengetahui tipe soal yang dibuat oleh kelompok lain tersebut. Pembelajaran problem posing learning akan memungkinkan peserta didik menggunakan kemampuan kreativitas peserta didik serta dapat meningkatkan kemampuan dalam indikator kreativitas peserta didik seperti fluency, flexibility dan originality jika dibandingkan dengan pembelajaran konvensional.

Hasil analisis data diperoleh bahwa pembelajaran problem posing cukup berpengaruh terhadap kreativitas peserta didik yaitu sebesar $62,38 \%$. Sedangkan untuk perbandingan ratarata setiap indikator kreativitas dari kedua kelas dapat terlihat pada Tabel 4.7. Pada indikator fluency rata-rata kelas eksperimen lebih tinggi yaitu 79,58 jika dibandingkan dengan kelas kontrol yaitu 60,00. Sehingga dapat dikatakan bahwa peserta didik pada kelas eksperimen mampu memberikan jawaban berbeda lebih dari satu dengan lancar daripada kelas kontrol. Penelitian Faelasofi (2017) juga mendapatkan hasil bahwa kemampuan fluency peserta didik kelas eksperimen lebih tinggi daripada kelas kontrol. Namun masih terdapat peserta didik yang tidak mampu menyelesaikan perhitungan padahal hanya tinggal mengoperasikannya saja.

Kemampuan peserta didik pada indikator flexibility kelas eksperimen memperoleh ratarata 63,61 sedangkan pada kelas kontrol memperoleh rata-rata 48,61 meski terdapat perbedaan yang cukup jauh namun kemampuan flexibility kelas eksperimen masih terbilang rendah karena belum mencapai rata-rata 75,00. Pada aspek ini peserta didik pada kelas eksperimen telah mampu memberikan alternatif penyelesaian yang berbeda-beda atau bervariasi daripada peserta didik kelas kontrol. Faelasofi (2017) dalam penelitiannya juga mendapatkan hasil bahwa 
perbandingan kemampuan flexibility peserta didik kelas eksperimen lebih tinggi dibandingkan peserta didik kelas kontrol. Namun terdapat peserta didik yang hanya mampu memberikan alternatif penyelesaian yang biasanya digunakan. Peserta didik hanya terpaku pada cara atau penyelesaian yang biasanya diberikan oleh pendidik.

Kemampuan peserta didik pada aspek originality kelas eksperimen memperoleh ratarata 43,30 sedangkan pada kelas kontrol memperoleh rata-rata sebesar 13,75. Hal ini terlihat bahwa kemampuan peserta didik dalam memberikan alternatif penyelesaian dari pemikiran mereka sendiri atau dari ide-ide baru juga masih rendah, meski demikian peserta didik pada kelas eksperimen telah mampu menggunakan kemampuannya untuk menyelesaikan masalah dengan ide baru. Moma (2015:29) dalam penelitiannya mengatakan bahwa "berpikir kreatif adalah aktivitas mental yang terkait dengan kepekaan terhadap suatu masalah, mempertimbangkan informasi baru dan ide-ide yang tidak biasanya dengan suatu pikiran terbuka peserta didik menggunakan kemampuan berpikir terbuka serta berkaitan dengan penyelesaian masalah". Selain itu, dalam proses perhitungan terdapat peserta didik yang masih salah dan penggunaan rumus tidak sesuai dengan pertanyaan.

Perbedaan kemampuan kreativitas peserta didik pada kelas eksperimen yang menggunakan model pembelajaran problem posing yang lebih meningkat daripada peserta didik pada kelas kontrol yang menggunakan model pembelajaran konvensional. Meski demikian masih terdapat kendala dalam pelaksanaan penelitian misalnya peserta didik masih mengalami banyak kesulitan dalam mengajukan masalah dikarenakan peserta didik jarang mengajukan masala, peserta didik dibentuk menjadi beberapa kelompok sehingga situasi dan kondisi di kelas lebih berisik daripada biasanya, dan pemahaman peserta didik dalam mengajukan penyelesaian yang memiliki banyak penyelesaian juga masih rendah.

\section{PENUTUP}

Berdasarkan hasil penelitian dan pembahasan diperoleh kesimpulan bahwa penerapan model pembelajaran problem posing mampu memberikan pengaruh terhadap kreativitas peserta didik jika dibandingkan dengan pembelajaran konvensional. Hal ini terlihat dari nilai signifikan yaitu $0,000<0,05$ sehingga $\mathrm{H}_{0}$ ditolak $\mathrm{H}_{1}$ diterima. Besar pengaruh model pembelajaran problem posing yaitu sebesar $62,38 \%$ yang artinya model pembelajaran problem posing cukup berrpengaruh terhadap kreativitas peserta didik.

\section{DAFTAR PUSTAKA}

Faelasofi, R. 2017. Identifikasi Kemampuan Berpikir Kreatif Matematika Pokok Bahasan Peluang. Jurnal Edumath, 3 (2): 155-163. (Online),

(http://ejournal.stkipmpringsewu-lpg.ac.id), diakses 02 Januari 2015.

Mahendra, R., Slamet, I dan Budiyono. 2017. Problem Posing with Realistic Mathematics Education Approach in Geometry Learning. International Conference on Mathematics and Science Education (ICMScE), 895. (Online), (http://iopscience.iop.org), diakses 01 Januari 2018.

Mahmudi, A. 2007. Meningkatkan Kreativitas Siswa Melalui Problem Posing. Jurnal pendidikan matematika, 3 (1) : 43-50. (Online), (http://www.journal.uny.ac.id), diakses 28 Oktober 2017.

Mahmudi, A. 2008. Tinjauan Kreativitas Dalam Pembelajaran Matematika. Jurnal pendidikan matematika, 4 (2). (Online), (http://www.journal.uny.ac.id), diakses 28 Oktober 2017.

Moma, L. 2015. Pengembangan Instrumen Kemampuan Berpikir Kreatif Matematis Untuk Siswa SMP. Jurnal Matematika dan Pendidikan Matematika, 4 (1) : 27-41. (Online), (http: http://ejournal.unkhair.ac.id), diakses tanggal 31 Januari 2018. 
Permendikbud No 22 Tahun 2016 Tentang Standar Proses Pendidikan Dasar dan Menengah. 2016. Badan Standar Nasional Pendidikan. (Online), http://bsnpindonesia.org, diakses 10 Oktober 2017.

Silver, E.A. 1997. Fostering Creativity Throught Instruction Rich In Mathematical Problem Solving And Problem Posing. Internasional Reviews on Mathematical Education, 29 (3) : 75-80. (Online), diakses 28 Desember 2017.

Siswono, TEY. 2004. Mendorong Berpikir Kreatif Siswa melalui Pengajuan Masalah (Problem Posing). Makalah disampaikan pada Konferensi Himpunan Matematika Indonesia, Denpasar, Bali 23-27 Juli 2004.

Siswono, TYE. 2007. Meningkatkan Kemampuan Berpikir Kreatif Siswa Melalui Pengajuan Masalah Dan Pemecahan Masalah. Makalah disampaikan pada Simposium Nasional Penelitian Pendidikan yang diselenggarakan oleh Pusat Studi Kebijakan Departemen Pendidikan Nasional di Jakarta, 25-26 Juli 2007.

Siswono, TEY. 2009. Upaya Meningkatkan Kemampuan Berpikir Kreatif Siswa melalui Pengajuan Masalah. Laporan Penelitian. Jurusan Matematika FMIPA UNESA.

Suastika, I.K. 2017. Mathematical Learning Model of Open Problem Posing Learning to Develop Students Creativity. IEJME-Mathematics Education, 12 (6) : 569-577. (Online), (http://www. Iejme.com), diakses 04 Januari 2018.

Sugihardjo., Mardiyana dan Riyadi. 2014. Eksperimentasi Model Pembelajaran Problem Posing dan Problem Solving pada Materi Trigonometri ditinjau dari Kreativitas Peserta Didik Kelas XI IPA SMA Se-Kabupaten Kudus Tahun Pelajaran 2013/2014. Jurnal Elektronik Pembelajaran Matematika, 2 (5) : 454-464. (Online), (http://jurnal.fkip.uns.ac.id), di akses tanggal 30 Desember 2017.

Sugiyono. 2015. Metode Penelitian Kuantitatif, Kualitatif dan $R$ \& D. Bandung: Penerbit Alfabeta

Ulfah, U,. Prabawanto, S., and Jupri, A. 2017. Student's Mathematical Creative Thinking Through Problem Posing Learning. Journal Of Physycs:Conference Series, 895. (Online), (http://iopscience.iop.org), diakses 8 Januari 2018

Zakaria, E., and Ngah, N. 2011. Preliminary Analysis of Student's Problem-Posing Ability and Relationship to Attitudes Towards Problem Solving. Research Journal of Applied Sciences, Engineering and Technology 3 (9) : 866 - 870 ISSN : 2040-7467. (Online), (http://www.researchgate.net/publication/267788611), diakses 25 Februari 2018. 